\title{
Geophysical Analysis of the Salmon Peak Formation near Amistad Reservoir Dam, Val Verde County, Texas, and Coahuila, Mexico, March 2006, to Aid in Piezometer Placement
}

\author{
By Gregory P. Stanton ${ }^{1}$, Wade H. Kress ${ }^{2}$, Andrew P. Teeple ${ }^{2}$, Michael L. Greenslate ${ }^{1}$, and \\ Allan K. Clark ${ }^{3}$ \\ ${ }^{1}$ U.S. Geological Survey, 8027 Exchange Drive, Austin, Texas 78754 \\ ${ }^{2}$ U.S. Geological Survey, 944 Arroyo Drive, San Angelo, Texas 76903 \\ ${ }^{3}$ U.S. Geological Survey, 5563 De Zavala Road, Suite 290, San Antonio, Texas 78249
}

\begin{abstract}
Since 1992, numerous sinkholes have developed northwest of the Amistad Reservoir dam on the Rio Grande. Increases in the discharge of springs south of the dam, on the western side of the Rio Grande, in Coahuila, Mexico, have been documented. In 1995 the Mexico Section of the International Boundary and Water Commission (IBWC) completed a study of the western embankment (Coahuila, Mexico) of the dam that included surface geophysics, borehole geophysics, and installation of piezometers to learn more about subsurface conditions. As part of a 5-year safety inspection in 2005, technical advisors recommended that one line of similarly constructed piezometers be installed on the eastern embankment (Val Verde County, Texas) of the dam for comparison of water levels (potentiometric head) on both the western and eastern embankments of Amistad Reservoir dam. To provide technical assistance for the horizontal and vertical placement of piezometers on the eastern embankment of Amistad Reservoir dam, the U.S. Geological Survey, in cooperation with the U.S. Section of the IBWC, conducted a study along both the western and eastern embankments of Amistad Reservoir dam. The study involved an integrated approach using surface and borehole geophysical methods. In the western embankment investigation, geological and geophysical characteristics that indicate relatively large water-yielding properties of the Salmon Peak Formation were identified. The direct-current (DC) resistivity method was selected as the surface geophysical reconnaissance technique to correlate relatively large water-yielding properties of the Salmon Peak Formation, identified from analysis of borehole geophysical logs, with variations in subsurface resistivity. The dipole-dipole array and the reciprocal Schlumberger array were selected as the most applicable DC resistivity arrays. Two resistivity units were identified in both the dipole-dipole array data and the reciprocal Schlumberger array data along DC resistivity profiles on both embankments. Resistivity unit 1 generally is of relatively low resistivity, ranging from 45 to $150 \mathrm{ohm}$-meters compared with resistivity unit 2 , which ranges from 120 to 345 ohm-meters (depending on the DC array type). The presence of mapped sinkholes in the reservoir north of the western embankment study area and the zone of increased water content (as indicated by zones of low neutron log count rates in nearby piezometers) leads to the conclusion that resistivity unit 1 is a preferential flow path where surface water from Amistad Reservoir is forced into the ground-water system (because of increased head from the reservoir). In the eastern embankment investigation, trends in the spatial distribution of sinkholes and the occurrence of weathered zones were identified from geologic descriptions of cores. The correlation of surface geophysical DC resistivity, historical lithologic data, and general trend of documented sinkholes along the eastern end of the eastern embankment profile were used to justify further exploration (drilling of piezometers) in the eastern expression of resistivity unit 1 . The spatial location of the piezometers and the screened intervals were selected to best match the locations of the screened intervals of the western embankment piezometers. Six piezometers were installed on the eastern embankment and logged using borehole geophysical techniques. Surface DC resistivity sections superimposed on the resistivity logs for two piezometers indicate three discernible resistivity units that correlate with resistivity units 2,1 , and 2 , respectively, identified in the western embankment study area. Resistivity units 1 and 2 in the DC resistivity profiles generally correspond with low and high resistivity zones, respectively, on the normal and lateral resistivity logs collected in the nearby piezometers at the time of installation ( Stanton and others, 2007, Stanton and others, 2008).
\end{abstract}




\section{REFERENCES}

Stanton, G.P., Kress, W.H., Teeple, A.P., Greenslate, M.L., and Clark, A.K., 2007, Geophysical analysis of the Salmon Peak Formation near Amistad Reservoir dam, Val Verde County, Texas, and Coahuila, Mexico, March 2006, to aid in piezometer placement: U.S. Geological Survey Scientific Investigations Report 2007-5143, 70 p. http://pubs.usgs.gov/sir/2007/5143/.

Stanton, G.P., Kress, W.H., Teeple, A.P., and Clark, A.K., 2008, Geophysical analysis of the Salmon Peak Formation near Amistad Reservoir dam, Val Verde County, Texas, and Coahuila, Mexico, March 2006, to aid in piezometer placement in $21^{\text {st }}$ Symposium on the Application of Geophysics to Engineering and Environmental Problems (SAGEEP), Philadelphia, Pennsylvania, April 6-10, 2008, Proceedings: 18 p. 